\title{
Peran Mediasi Perilaku Eksplorasi Karier dalam Pengaruh Dukungan Teman terhadap Adaptabilitas Karier Mahasiswa
}

\author{
Rifda Nabila Afifah, Rose Mini Agoes Salim \\ Universitas Indonesia, \\ Jl. Lkr. Kampus Raya Jl. Mawar No.5 3 8, Kota Depok \\ E-mail: rifnabilafifah@gmail.com
}

\begin{abstract}
ABSTRAK
Berbagai tantangan perlu dihadapi dengan perubahan Revolusi Industri 4.0 yang membuat $75-375$ juta pekerja mengalami pergeseran profesi. Bahkan, banyak profesi yang terkena imbasnya karena digantikan oleh mesin-mesin. Terkaitdengan perkembangan karir pada mahasiswa yang perlu mengeksplor karir mereka, hal tersebut menjadi tantangan tersendiri bagi merekauntuk beradaptasi dalam menghadapi perubahan akibat revolusi ini. Tujuan penelitian ini adalah untuk menguji peran perilaku eksplorasi karier dalam memediasi pengaruh dukungan teman terhadapadaptabilitas karier mahasiswa tingkat akhir. Partisipan penelitian berjumlah 538 mahasiswa tingkat akhir di Jakarta, Bogor, Depok, Tangerang, dan Bekasi (JABODETABEK). Pengambilan sampeldilakukan dengan metode convenience sampling. Penelitian ini menggunaan tiga alat ukur, yaitu Career Related Peer Support (Zhang \& Huang, 2018), Career Exploration Survey (Salim \& Preston, 2019) dan Career Adapt-Ability Scale (Sulistiani, Suminar, dan Hendriani, 2019). Pengolahan data dilakukan menggunakan simple mediation model 4 PROCESS for SPPS by Hayes (2013). Hasil analisis mediasi menjelaskan bahwa dukungan teman mempengaruhi adaptabilitas karier pada mahasiswa tingkat akhir melalui perilaku eksplorasi karier secara penuh, dengan nilai indirect effect sebesar 0,1347. Mahasiswa yang mempersepsikan dukungan teman terkait karier cenderung memunculkan perilaku mencari informasi, mengikuti kegiatan terkait karier (magang, seminar, dll), dan meninjau kembali informasi yang mereka dapat yang berdampak pada peningkatkan kemampuan adaptabilitas karier dalam menghadapi berbagai tantangan untuk menghadapi transisi kuliah-ke-kerja.
\end{abstract}

Kata kunci: mahasiswa; adaptabilitas karier; dukungan teman; perilaku eksplorasi karier

\begin{abstract}
There are many challenges need to be faced by college students due to thechange brought byhe Industrial Revolution 4.0, which made 75- 375 million workers subtitutedin their profession. In fact, many professions wereaffected because of their replacementbymachinery. Consistent with the career development of college students who need to explore their careers, this phenomenon becamea challenge for them to adapt in facing this revolutionary change. This study examined the role of career exploration behavior on mediatingthe influence of peer support on the career adaptability of final-degree students. The research participants were538 final year students in Jakarta, Bogor, Depok, Tangerang, and Bekasi (JABODETABEK). The samplewas collected throughconvenience sampling method. This study usedthree instruments: Career Related Peer Support (Zhang \& Huang, 2018), Career Exploration Survey (Salim \& Preston, 2019) and Career Adapt-Ability Scale (Sulistiani, Suminar, dan Hendriani, 2018 The simple mediation model 4 PROCESS for SPSS by Hayes is used for data processing. The result of mediation analysis showsthat peer support influences career adaptability in the final year students through career exploration behavior, withan indirect effect of 0,1347. Students who perceive appropriate peer support related to their career tend to show information seeking behavior, participate in career-related activities (internships, seminars, etc.), and review the information they have obtained which has an impact on increasing career adaptability ability in facing various challenges to face the school-to-work transition.
\end{abstract}

Keyword: college students; career adaptability; peer support; career exploration behavior. 


\section{PENDAHULUAN}

Berdasarkan perspekif teori perkembangan, mahasiswa berada dalam tahap emerging adulthood (18- 25 tahun), masa transisi dimana merekaperlu melakukan berbagai kegiatan eksplorasi terkait karir dan mengembangkan kemampuannya untuk mengatasi beragam tantangan dalam karir yang mereka pilih (Arnett, 2015). Mahasiswa membutuhkan tingkat keterampilan dan kemampuan adaptasi dari waktu ke waktu selama masa transisi (Murphy et al., 2010). Mahasiswa memiliki tantangan tersendiri dalam mengembangkan karir karena banyak peluang yang bisa didapat namun jugabanyak tantangan yang dihadapi. Oleh karena itu, perencanaan dan sikap adaptif menjadi sangat penting pada tahap emerging adulthood (Marshall \& Butler, 2015). Hal ini juga dapat dilihat dari perspektif teori karir, dimana pada usia 15-24 tahun mahasiswa memasuki tahapan eksplorasi yang menekankanperlunya mengembangkan keterampilan dan mencari berbagai pengalaman kerja (Super, 1980).

Pada saat ini, Indonesia sedang melakukan perubahan terbaru dalam menghadapi Revolusi Industri 4.0. Di Indonesia, Revolusi Industri 4.0 menjadi tantangan tersendiri dalam dunia pendidikan, khususnya di perguruan tinggi. Gambaran besar dari perubahan Revolusi Industri 4.0 yaitu adanya peran teknologi informasi dan mesin yang dimanfaatkan sepenuhnya di hampir keseluruhan kebutuhan manusia, dimana hal ini dapat mengubah pekerjaan yang dilakukan oleh manusia pada proses industri (Risdianto, 2019). Dampak lainnyayaitu diprediksikan pada lima tahun yang akan datang, 52,6 juta jenis pekerjaan akan tergantikan ataupun hilang (Manyijka et al., 2017). Revolusi Industri 4.0 membuat 75-375 juta pekerja mengalami pergeseran profesi (MENRISTEKDIKTI, 2019). Bahkan, banyak profesi manapun terkena imbasnya karena digantikan dengan mesin-mesin (MENRISTEKDIKTI, 2019). Selain itu, MIKTI dan Teknopreneur (2018) menjelaskan bahwa saat ini terdapat 992 startup yang berkembang di Indonesia, yang bergerak di berbagai bidang seperti e-commerce, Fintech, startup Game, danlain-lain. Ke 992 startup ini menyerap tenaga kerja hingga mencapai 55.903 orang dengan mayoritas $80,32 \%$ diantaranya berpendidikan S1,
DIPLOMA 9,84\%, SMA 9,21\% dan sebesar $0,63 \%$ bergelar S2.

Focus group discussion (FGD) dilakukan kepada sembilan mahasiswa terkait rencana karir. Hasil FGD menunjukkan bahwa 7 dari 9 mahasiswa memilih pekerjaan yang berbeda dengan jurusannya karena selama menjalani masa perkuliahan, mereka menyadari bahwa materi yang diajarkan bukanlah bidang yang diminati. Hal ini menggambarkan kontrol karir mahasiswa, yang mana kontrol karir merujuk pada rasa bertanggung jawab untuk membentuk diri dan lingkungan untuk memenuhi apa yang akan datang berikutnya dengan menggunakan disiplin diri, usaha, dan ketekunan (Savickas \& Porfeli, 2012). Hasil FGD ini didukung oleh penelitian Zacher (2015) yang menjelaskan bahwa memiliki pilihan yang non-linear antara kuliah dengan pekerjaan akan berpengaruh pada adaptasi di lingkungan pekerjaan. Selain itu, kesembilan mahasiswa FGD mengetahui apa saja pekerjaan yang berkaitan dengan jurusan pilihan mereka. Walaupun demikian, mereka merasa tidak tertarik dan tidak mendalami hal tersebut, sehingga memilih pekerjaan yang menurut mereka lebih menarik dan memberikan pengaruh positif. Hal ini menggambarkan kepedulian karir mahasiswa, yang mana kepedulian karir merujuk pada kepedulian individu tentang masa depan dan mempersiapkan apa yang akan terjadi selanjutnya (Savickas \& Porfeli, 2012).

Selain itu, 6 dari 9 mahasiswa belum bertanggung jawab atas pilihan karirnya, seperti menyiapkan diri mereka untuk dunia yang akan mereka pilih, tidak ikut jobfair walaupun mengetahui keberadaannya di universitasnya, tidak mau mengikuti workshop, dan tidak melakukan kegiatan yang mengasah keterampilan mereka untuk menunjang keberhasilan karirnya. Hal ini menggambarkan keingintahuan karir mahasiswa. Dari hasil jawaban kesembilan mahasiswa, secara keseluruhan mereka merasa percaya dengan pilihan karirnya mampu menunjang keberhasilan hidup, namun mereka tidak percaya diri dengan pilihan karir yang sesuai dengan jurusan mereka karena mereka tidak tertarik dan hal tersebut tidak membantu mereka untuk lebih mampu beradaptasi. Hal ini menggambarkan keyakinan akan karir mahasiswa. Hasil FGD ini menggambarkan bahwa para mahasiswa kurang memiliki kesiapan pada masa 
transisi pemilihan karir dan bekerja di era Revolusi Industri 4.0 ini. Oleh karena itu, penting untuk meningkatkan adaptabilitas karir pada mahasiswa.

Hal yang dialami oleh mahasiswa tersebut dapat dijelaskan dengan kemampuan adaptabilitas karir yang dikemukakan oleh Savickas (1997). Adaptabilitas karir adalah kesiapan untuk menghadapi tugas yang terprediksi maupun tidak terprediksi untuk berpartisipasi dalam perubahan kondisi dan tugas pekerjaan (Savickas, 1997). Pemahaman pentingnya adaptabilitas karir akan berdampak pada jenjang karir sebagaimana Konstam et al. (2015) menjelaskan bahwa adaptabilitas karir sangat penting bagi mahasiswa untuk menguasai masa transisi dari kuliah ke lingkungan kerja. Selain itu, adaptabilitas karir dapat meningkatkan peluang individu untuk menemukan pekerjaan yang cocok (Koen et al., 2012). Apabila individu tidak memiliki adaptabilitas karir akan berdampak pada individu itu sendiri, yaitu mereka cenderung akan mengalami perasaan-perasaan yang mengarah pada ketidaksiapan karir, frustrasi, mengalami tekanan dan kecemasan (Martin et al., 2006; Masuna, 2015). Di sisi lain, individu dengan adaptabilitas karir yang tinggi akan mampu menyesuaikan diri dalam mengahadapi segala perubahan pada situasi pekerjaannya yang terus berubah (Ebenehi et al., 2016). Oleh karena itu, kemampuan adaptabilitas karir sangat penting dimiliki oleh mahasiswa untuk membantu menghadapi berbagai perubahan dan tantangan karirnya.

Pengembangan kemampuan adaptabilitas karir dapat dijabarkan dalam tiga hal utama yakni perbedaan individual, perkembangan manusia, dan lingkungan sosial (Savickas, 1997). Perbedaan individual meliputi kemampuan beradaptasi tiap individu saat mengatasi segala situasi yang dipengaruhi faktor perkembangan kognitif, dan afektif (Savickas, 1997). Perkembangan manusia mengacu pada tugas perkembangan manusia sepanjang hidupnya (Savickas, 1997), yang mana dalam penelitian ini mengacu pada perkembangan karir menurut Super (1980) yang memasuki tahap eksplorasi. Dilihat dari konteks sosial, sudah banyak penelitian yang melihat hubungan antara dukungan orang tua dengan adaptabilitas karir (Ebenehi et al., 2016; Ginevra et al., 2015; M. Guan et al., 2016; Han \& Rojewski, 2014; Wang \& Fu, 2015). Begitu pula dengan penelitian Indianti (2015), dimana di
Indonesia sendiri dukungan teman memberikan pengaruh yang paling besar terhadap adaptabilitas karier dibandingkan dukungan dari orang tua dan dosen. Hal ini dikarenakan semakin beranjak dewasa, bentuk dukungan yang dibutuhkan lebih bersifat pemberian nasihat, pemberian umpan balik dari peran yang merasakan hal yang sama, dan dalam konteks mahasiswa, peran yang sama adalah temannya sendiri.

Dukungan teman terkait karier terdiri dari tiga dimensi yaitu informasi dan saran mengenai karier yang merujuk pada pemerolehan informasi dan saran pekerjaan yang didapatkan individu dari teman. Dimensi dukungan emosional merujuk pada kenyamanan, dorongan, dan pendampingan dari teman selama proses mengeksplor karier. Dimensi peer role model merujuk pada tindakan teman-teman yang individu ikuti. Dukungan teman memiliki pengaruh terbesar pada perilaku sehari-hari mahasiswa di lingkungan perkuliahan (Steinberg, Dornbusch, \& Brown, 1992). Dukungan teman memiliki peran penting terhadap motivasi dan prestasi akademik mahasiswa (Wentzel et al., 2017). Hal ini didukung oleh penelitian Hlad'o et al., (2019), dukungan teman sebagai salah satu faktor eksternal yang memiliki pengaruh yang signifikan terhadap adaptabilitas karier. Namun, penelitian yang dilakukan oleh Yousefi et al., (2011) menemukan bahwa dukungan dari orang tua, teman, dan sumber lainnya tidak menunjukkan adanya hubungan apapun dengan adaptabilitas karier pada mahasiswa di Spanyol.

Dukungan teman memiliki peran positif dalam eksplorasi dan pengembangan karier individu (Zhang \& Huang, 2018). Menurut Felsman dan Blustein (1999), semakin banyak individu mendapatkan dukungan dari teman, maka individu akan terdorong untuk mencari tahu informasi mengenai kariernya. Selain itu menurut Kracke (2002), semakin seringnya berdiskusi dengan temanteman tentang karier dapat memengaruhiperilaku pencarian informasi dan dapat memprediksi tingkat eksplorasi karier selama periode 6 bulan berikutnya. Selain itu, semakin tinggi individu mempersepsikan dukungan teman, mereka akan semakin terbantu untuk mengeksplor atau mencari informasi terkait kariernya (Turkan et al., 2014; Geerlings et al., 2016; Turkan, De Oliveira, Luciana, Lee, 2014). Begitu juga dengan penelitian yang dilakukan Zhang dan 
Huang (2018) yang menjelaskan bahwa semakin sering mahasiswa mendapatkan dukungan teman terkait karier, maka dukungan tersebut akan membantu mereka untuk mencari tahu dan mengeksplor kariernya.

Di sisi lain, hasil temuan Guan et al. (2015) menjelaskan bahwa perilaku eksplorasi karier pada mahasiswa akan berfungsi sebagai faktor yang berpengaruh terhadap adaptabilitas karier dan menjadi mediator penuh pada pengaruh perilaku karier orang tua terkait karier (career-specific parental behaviors) terhadap adaptabilitas karier. Perilaku karier orang tua terkait karier (careerspecific parental behaviors) mampu mengembangkan kompetensi-kompetensi yang dimiliki mahasiswa, namun di sisi lain dapat mengurangi kemandirian mahasiswa karena terlalu banyak campur tangan dari orang tua mereka dalam mempersiapkan kariernya. Dengan demikian, perilaku eksplorasi karier membantu mahasiswa untuk mengeksplor informasi dan peluang yang berharga, dan mempersiapkan diri untuk menghadapi berbagai tantangan karier. Oleh karena itu, perilaku eksplorasi karier berfungsi sebagai penghubung utama atau mediator antara perilaku karier orang tua terkait karier (career-specific parental behaviors) dan adaptabilitas karier.

Adaptabilitas karier memiliki empat dimensi. Pertama, dimensi kepedulian karier (career concern) yang merujuk pada kepedulian individu tentang masa depan dan mempersiapkan apa yang akan terjadi selanjutnya. Kedua, dimensi control karier (career control) yang merujuk pada rasa bertanggung jawab untuk membentuk diri dan lingkungan untuk memenuhi apa yang akan datang berikutnya dengan menggunakan disiplin diri, usaha, dan ketekunan. Ketiga, dimensi keingintahuan karier (career curiosity) yang merujuk kepada kegiatan eksplorasi dan pencarian informasi yang dibutuhkan dari bidang pekerjaan atau karier tertentu serta bereksperimen dan mencari berbagai macam kesempatan untuk merasakan pengalaman karier yang diinginkan. Keempat,dimensi keyakinan karier (career confidence) yang merujuk kepada antisipasi masalah yang akan dihadapi yang membentuk kemampuan untuk melakukan pemecahan masalah terhadap masalah yang mungkin saja dihadapi jika seseorang memilih jalur karier tertentu (Savickas \& Porfeli, 2012).
Untuk mengembangkan adaptabilitas karier, individu harus terus mendapatkan informasi tentang karakteristik diri dan lingkungan kerja melalui berbagai pengalaman pribadinya (Savickas \& Porfeli, 2012). Pengalaman pribadi dapat dijelaskan dari perilaku eksplorasi karier yang mengacu pada kegiatan yang memungkinkan individu untuk mengumpulkan dan menganalisis informasi yang relevan dengan pengembangan karier mereka (Blustein, 1997; Stumpf et al., 1983; Super et al., 1963). Perilaku eksplorasi karier memiliki dua dimensi, yaitu eksplorasi diri dan eksplorasi lingkungan (Stumpf et al., 1983). Eksplorasi diri berfokus pada bagaimana individu mendefinisikan dan mengeksplorasi kepentingan diri sendiri, pengalaman sebelumnya, dan tujuan kariernya. Sementara itu pada eksplorasi lingkungan, individu lebih aktif mengumpulkan informasi baru mengenai pekerjaan, organisasi yang memungkinkan untuk membantu memudahkan dalam memutuskan pengambilan karier dan meninjau berbagai macam pilihan karier untuk mempertimbangkan terlebih dahulu sebelum menentukan kariernya (Greenhaus \& Callanan, 2006). Melalui eksplorasi diri, mahasiswa dapat melihat ketertarikan, nilai, serta pengalaman dan membentuk gambaran yang jelas mengenai diri mereka dan bagaimana atribut internal tersebut membentuk karier mereka di masa depan Blustein dan Flum (1999). Eksplorasi lingkungan juga dapat membantu mahasiswa dalam keputusan karier dengan mengumpulkan informasi mengenai pekerjaan, dan organisasi (Ketterson \& Blustein, 1997). Dimensi eksplorasi lingkungan dan eksplorasi diri dapat secara efektif melengkapi individu dalam perubahan di kehidupan dan kariernya (Murphy et al., 2009). Hal ini mengindikasikan bahwa eksplorasi karier berpeluang untuk meningkatkan daya adaptabilitas karier seseorang dengan cara mengeksplorasi diri dan lingkungan.

Seperti yang sudah dijelaskan di paragrafsebelumnya, dukungan teman dan perilaku eksplorasi karier berpengaruh terhadap adaptabilitas karier (Hlad'o et al., 2019). Namun, hasil penelitian mengenai dukungan teman terhadap adaptabilitas karier masih inkonsisten. Adanya inkonsistensi pengaruh dua variabel tersebut mendorong penelitian ini dilakukan untuk menguji faktor internal eksplorasi karier dalam konteks peran mediasi. Hal 
tersebut karena beberapa studi menunjukkan ada keterkaitan antara dukungan teman dengan perilaku eksplorasi karier individu (Geerlings et al., 2016; Turkan et al., 2014; Zhang \& Huang, 2018). Melalui perilaku eksplorasi karier, mahasiswa dapat melihat ketertarikan, nilai, serta pengalaman dan membentuk gambaran yang jelas mengenai diri mereka dan bagaimana atribut internal tersebut membentuk karier mereka di masa depan (Ketterson \& Blustein, 1997). Oleh karena itu, penelitian ini bertujuan untuk menguji peran perilaku eksplorasi karier dalam memediasi pengaruh antara dukungan teman terhadap adaptabilitas karier pada mahasiswa. Dengan hipotesa penelitian bahwa perilaku eksplorasi karier berperan menjadi mediator penuh pada pengaruh dukungan teman terhadap adaptabilitas karier.

\section{METODE}

Penelitian ini menggunakan pendekatan kuantitatif dengan menggunakan desain penelitian kuesioner self-report untuk menguji perilaku individu. Penelitian survei digunakan atas dasar pertimbangan berikut: (a) representasi tinggi; (b) pengumpulan data yang mudah; (c) signifikansi statistik yang baik; (d) subjektivitas peneliti kecil (Werang, 2018). Populasi penelitian ini adalah mahasiswa, pada awalnya data yang didapat adalah 602 partisipan namun setelah dilakukan cleaning data yang termasuk dalam kategori sampel penelitian ini berjumlah 538 partisipan. Teknik pengambilan sampling menggunakan metode convenience sampling. Waktu pelaksanaan pengambilan data berlangsung selama bulan Maret-April 2020 dengan menyebarkan kuesioner secara online melalui Google Form. Pengambilan data dilakukan secara online karena keadaan negara sedang dalam pandemi COVID-19 sehingga penyebaran data secara langsung tidak memungkinkan untuk dilakukan.

Alat ukur Career Adapt-Abilities Scale (CAAS) yang digunakan adalah alat ukur yang diadaptasi ke dalam bahasa Indonesia oleh Sulistiani et al. (2019). Alat ukur ini pada bentuk aslinya terdiri dari 24 aitem yang menghasilkan total skor untuk menilai adaptabilitas karier individu (Savickas \& Porfeli, 2012). Alat ukur ini terdiri dari 4 dimensi adaptabilitas karierkarier yaitu kepedulian karierkarier, dimensi pengendalian karierkarier, dimensi keingintahuan karierkarier, dan dimensi keyakinan diri karierkarier. Pada setiap pernyataan alat ukur adaptabilitas karier terdapat lima pilihan jawaban skala likert, yaitu tidak kuat (1) sampai sangat kuat (5). Contoh aitem diataranya "menyadari akan pilihan-pilihan pendidikan dan pilihan karierkarier yang harus saya buat" dan "bertanggung jawab atas tindakan saya". Data uji reliabilitas menggunakan Cronbach Alpha, hasil reliabilitas pada alat ukur ini secara keseluruhan sebesar 0,952. Sementara itu, hasil uji validitas alat ukur secara keseluruhan menggunakan validitas konstruk dengan mengukur konsistensi internal melalui metode CorrectedItem-Total Correlation dari korelasi Pearson dengannilai $r$ berkisar antara 0,483-0,784. Hasil uji reliabilitas dan validitas menunjukkan bahwa alat ukur tersebut reliabel dan valid dalam mengukur konstruk yang mau diukur, sehingga peneliti tidak melakukan revisi aitem atau penghapusan aitem. Berdasarkan skala adaptabilitas karierkarier yang mana memiliki rentang nilai 1 hingga 5 maka nilai mean partisipan adalah 3, untuk nilai mean yang lebih besar dari 3 maka tergolong tinggi, dan nilai mean yang lebih kecil dari 3 maka tergolong rendah.

Dukungan teman diukur dengan skala Career- related Peer Support yang memiliki 15aitem (Zhang \& Huang, 2018), dan terdiri dari tiga sub-skala, skala ini mengukur persepsi mahasiswa tentang informasi karierkarier dan saran (career information and suggestions) yang diberikan oleh teman (7 aitem), dukungan emosional (4 aitem), dan role model teman (4 aitem). Skala ini baru dikembangkan untuk digunakan dalam penelitian terbaru saat ini (Zhang \& Huang, 2018) yang sebelumnya sedikit sekali skala- skala mengenai dukungan teman terkait karierkarier. Partisipan penelitian diminta untuk menanggapi pernyataan tentang pilihan jawaban yang paling tepat mengenai aspek Career-Related Peer Support dengan menggunakan skala Likert mulai dari 1 (sangat tidak setuju) hingga 6 (sangat setuju). Contoh diantaranya adalah "Teman-teman saya menyarankan agar saya meningkatkan ketermpilan terkait pekerjaan yang saya pilih"; "Teman-teman memotivasi saya dan setuju dengan pengambilan keputusan karier saya"; "Saya akan mengikuti magang ketika saya melihat bahwa teman-teman saya berperilaku baik selama 
mereka magang". Data uji reliabilitas menggunakan Cronbach Alpha pada alat ukur ini secara keseluruhan adalah sebesar 0,901. Adapun hasil uji validitas alat ukur secara keseluruhan menggunakan validitas konstruk dengan mengukur konsistensi internal metode Corrected Item-Total Correlation dengannilai $r$ berkisar antara 0,317-0,710. Nilai tengah (mean) pada alat ukur dukungan teman adalah 3,500. Maka, partisipan yang memiliki nilai mean lebih dari 3,500 akan tergolong tinggi, dan nilai mean yang lebih kecil dari 3,500 akan tergolong rendah.

Perilaku eksplorasi karier diukur menggunakan versi singkat dari skala Career Exploration Survey (CES) (Salim \& Preston, 2019) yang dimodifikasi dari CES asli yang dikembangkan oleh Stumpf et al. (1983). CES asli digunakan untuk mengukur keyakinan yang berhubungan dengan karier tentang perilaku eksplorasi, proses eksplorasi, dan reaksi terhadap eksplorasi. CES yang diadaptasi oleh Salim \& Preston (2019) berisi 11 aitem yang digunakan untuk mengukur perilaku eksplorasi karier, termasuk eksplorasi lingkungan (lima aitem), eksplorasi diri (lima aitem) selama 3 bulan terakhir. Partisipan menggunakan skala Likert 5 poin $(1=$ tidak pernah $5=$ selalu) untuk menunjukkan frekuensi partisipasi mereka yang sesuai dengan pernyataan. Data uji reliabilitas menggunakan Cronbach Alpha pada alat ukur ini secara keseluruhan adalah sebesar 0,87 . Sementara itu, hasil uji validitas alat ukur secara keseluruhan menggunakan validitas konstruk dengan mengukur konsistensi internal metode Corrected Item-Total Correlation adalah nilai $r$ berkisar antara 0,275-0,714. Sementara itu, untuk menguji hipotesis penelitian dilakukan menggunakan simple mediation model 4 PROCESS for SPPS by Hayes (2013).

\section{HASIL DAN PEMBAHASAN}

Berdasarkan pada Tabel 1 tercantum hasil analisa deskriptif mengenai data demografi yang mencakup kelompok jenis kelamin, usia, dan tingkat semester. Didapatkan bahwa dari 538 partisipan, terdiri dari $69 \%$ mahasiswa yang berjenis kelamin perempuan yang mana dua kali lipat lebih banyak dibandingkan mahasiswa laki- laki 31\%. Dari 538 partisipan, rata-rata usia mahasiswa adalah 21,07 dan yang paling dominan dalam penelitian ini adalah mahasiswa berusia 21 tahun sebanyak $44,2 \%$. Selain itu, sebanyak 48,5\% mahasiswa yang dominan dalam penelitian ini sedang menempuh semester 8 .

Tabel 1. Analisa Deskriptif Data Demografis Jenis Kelamin, Usia, dan Semester

\begin{tabular}{lcc}
\hline Data Demografi & Frekuensi & Persentase (\%) \\
\hline Jenis Kelamin & & \\
Laki-laki & 167 & $31 \%$ \\
Perempuan & 371 & $69 \%$ \\
Usia & & \\
19 & 18 & $3,3 \%$ \\
20 & 134 & $24,9 \%$ \\
21 & 238 & $44,2 \%$ \\
22 & 105 & $19,5 \%$ \\
23 & 29 & $5,4 \%$ \\
24 & 9 & $1,7 \%$ \\
25 & 5 & $0,9 \%$ \\
Semester & & \\
Semester 6 & 242 & $45 \%$ \\
Semester 7 & 16 & $3 \%$ \\
Semester 8 & 261 & $48,5 \%$ \\
$>$ Semester 8 & 19 & $3,5 \%$ \\
\hline
\end{tabular}

Hasil temuan yang tertera pada Tabel 2 menunjukkan bahwa nilai mean dan standar deviasi dari data penelitian dan korelasi antara dukungan teman, perilaku eksplorasi karier, dan adaptabilitas karier pada mahasiswa. Berdasarkan nilai mean dari 538 pastisipan, didapatkan bahwa adaptabilitas karier yang dimiliki mahasiswa tergolong tinggi ( $\mathrm{M}$ $=4,019 ; \mathrm{SD}=0,537)$. Nilai mean dari tiap dimensi adaptabilitas karier cenderung tinggi, dengan nilai mean pada dimensi kepedulian karier $(\mathrm{M}=4,099$; $\mathrm{SD}=0,632)$, dimensi kontrol karier $(\mathrm{M}=4,044 ; \mathrm{SD}$ $=0,610)$, dimensi keingintahuan akan karier $(\mathrm{M}=$ 3,987; SD = 0,681), dan dimensi keyakinan karier $(\mathrm{M}=3,933 ; \mathrm{SD}=0,633)$. Begitu pula dengan skala perilaku eksplorasi karier, dari 538 partisipan yang ada dapat digolongkan memiliki perilaku eksplorasi karier yang tinggi $(M=3,180 ; S D=0,990$. Nilai mean dari tiap dimensi perilaku eksplorasi karier cenderung tinggi, dengan nilai mean pada dimensi eksplorasi diri $(\mathrm{M}=3,244 ; \mathrm{SD}=1,010)$ dan dimensi eksplorasi lingkungan $(\mathrm{M}=3,090 ; \mathrm{SD}=1,164)$. Hal ini berbeda dengan skala dukungan teman yangmana 
memiliki rentang nilai 1 hingga 6 . Berdasarkan Tabel 2, nilai mean dukungan teman dari 538 partisipan tergolong tinggi $(\mathrm{M}=3,517 ; \mathrm{SD}=1,243)$. Nilai mean dari tiap dimensi dukungan teman cenderung tinggi, dengan nilai mean pada dimensi dukungan informasi dan saran terkait karier $(\mathrm{M}=$ 3,525; SD $=1,135)$, dimensi dukungan emosional $(\mathrm{M}=3,501 ; \mathrm{SD}=1,633)$, dan dimensi peer role model $(\mathrm{M}=3,520 ; \mathrm{SD}=1,450)$. Hasil menunjukkan korelasi dua arah antara variabel dukungan teman dengan adaptabilitas karier berhubungan positif secara signifikan dengan nilai 0,200 . Hasil korelasi antara variabel dukungan teman dengan perilaku eksplorasi karier berhubungan positif secara signifikan dengan nilai 0,805 . Selain itu, hasil korelasi antara variabel perilaku eksplorasi karier dengan adaptabilitas karier dinyatakan positif dan signifikan dengan nilai 0,298 . Hal ini menunjukkan bahwa apabila mahasiswa intens untuk mengeksplor mengenai informasi terkait karier, maka hal tersbeut dapat membantu mahasiswa untuk lebih mudah beradaptasi dengan segala tantangan terkait karier yang akan dihadapinya.

Tabel 2. Mean, Standar Deviasi, dan Korelasi antara Variabel Penelitian

\begin{tabular}{lccccc}
\multicolumn{1}{c}{ Variabel } & Mean & SD & 1 & 2 & 3 \\
\hline $\begin{array}{l}\text { Adaptabilitas } \\
\text { karier }\end{array}$ & 4,019 & 0,537 & - & $0,200^{* *}$ & $0,298^{* *}$ \\
$\begin{array}{l}\text { Dukungan } \\
\text { teman }\end{array}$ & 3,517 & 1,243 & $0,200 * *$ & - & $0,805^{* *}$ \\
$\begin{array}{l}\text { Perilaku } \\
\text { eksplorasi }\end{array}$ & 3,180 & 0,990 & 0,298 & $0,805^{* *}$ & - \\
karier & & & & & \\
\hline$N=538 ; * * p<0,05$ & & & &
\end{tabular}

Menurut penelitian yang dilakukan oleh Hirschi (2009) dan Coetzee \& Harry (2014), jenis kelamin menjadi salah satu prediktor yang berpengaruh terhadap adaptabilitas karier. Namun data demografi yang didapat tidak seimbang secara kuantitas, sehingga data tidak dapat dianalisis lebih dalam terkait adaptabiltas karier berdasarkan jenis kelamin.

Berdasarkan Gambar 1, dalam menguji keterkaitan antara ketiga variabel dalam model penelitian, penelitian ini menggunakan simple mediation model 4 PROCESS for SPPS oleh Hayes (2013).

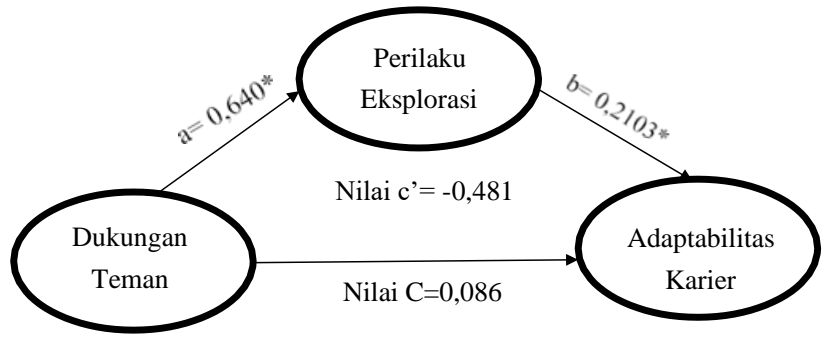

Gambar 1. Hasil Uji Mediasi Perilaku Eksplorasi
karier dalam Pengaruh Dukungan Teman
terhadap Adaptabilitas karier

Hasil temuan yang tertera pada Gambar 1 menunjukkan bahwa nilai pengaruh tidak langsung (indirect effect) dari variabel dukungan teman terhadap adaptabilitas karier melalui perilaku eksplorasi karier adalah sebesar $a b=0,134$. Adapun terdapat dua nilai interval kepercayaan (Confidence Interval/CI), yaitu BootLLCI (lower level for $C I$ ) dan BootULCI (upper level for CI). Apabila rentang nilai BootLLCI dan BootULCI tidak melewati angka nol (0), maka hal ini menjelaskan bahwa nilainya signifikan dan terdapat kemunculan peran mediasi. Pada penelitian ini, nilai BootLLCI (lower level for $C I)=0,085$ dan nilai BootULCI (upper level for $C I$ ) $=0,186$. Kedua nilai tersebut tidak melewati nilai 0 , maka pengaruh dukungan teman terhadap adaptabilitas karier sepenuhnya diperantarai oleh perilaku eksplorasi karier (full mediation).

Hasil korelasi menunjukkan bahwa dukungan teman berkorelasi secara positif dengan perilaku eksplorasi karier, dan perilaku eksplorasi karier berkorelasi positif dengan adaptabilitas karier pada mahasiswa. Hal ini sejalan dengan hipotesis penelitian yang dijelaskan pada pendahuluan, yangmana hasil uji mediasi membuktikan bahwa perilaku eksplorasi karier memediasi pengaruh dukungan teman terhadap adaptabilitas karier pada mahasiswa. Hal ini mengindikasikan bahwa pengaruh dukungan teman yang dipersepsikan oleh partisipan berupa dukungan informasi dan saran, dukungan emosional, serta panutan teman akan mempengaruhi perilaku mahasiswa dalam mencari, mengikuti kegiatan, mempertimbangkan, dan menelaah informasi terkait karier. Selanjutnya, hal ini akan berpengaruh pada peningkatkan kemampuan adaptabilitas karier mahasiswa yang 
berada pada tahap perkembangan memasuki dewasa awal (emerging adulthood). Artinya, berbagai bentuk dukungan yang didapatkan dari teman-teman terkait karier akan membantu mahasiswa untuk mengeksplor karier mereka, dan hal ini akan membantu mahasiswa beradaptasi untuk memasuki tahapan dewasa awal (emerging adulthood). Dukungan informasi dan saran terkait karier akan membantu mahasiswa untuk mencari pilihan karier mereka, yang kemudian dapat membantu mereka dalam merencanakan kariernya. Dengan memiliki perencanaan tersebut, mahasiswa akan membentuk sikap adaptif yang dapat menunjang berbagai tugas perkembangan pada tahap emerging adulthood, seperti salah satunya adalah pada masa transisi school to work.

Selain itu, temuan menunjukkan tidak ditemukannya pengaruh langsung (tanpa melalui variabel mediator) dukungan teman terhadap adaptabilitas karier walaupun saling berkorelasi. Hasil penelitian ini sejalan dengan penelitian yang dilakukan oleh Yousefi et al. (2011) yang dalam penelitiannya tidak adanya hubungan apapun antara dukungan teman terhadap adaptabilitas karier. Artinya, dukungan teman yang diterima oleh mahasiswa tidak dapat secara langsung membantu mereka memiliki kemampuan adaptabilitas karier yang baik dalam menghadapi tantangan dan perubahan yang terprediksi maupun tidak terprediksi.

Hasil penelitian ini bertentangan dengan penelitian sebelumnya yang menyatakan bahwa dukungan teman berpengaruh secara langsung terhadap adaptabilitas karier (Ataç, Dirik, \& Tetic 2018). Penelitian yang dilakukan oleh Ataç, Dirik \& Tetic(2018) yang menjelaskan bahwa semakin banyak dukungan teman yang dipersepsikan oleh mahasiswa di Turki akan berpengaruh secara signifikan terhadap adaptabilitas karier mereka, terlebih lagi dukungan teman memiliki hubungan yang positif dan signifikan terhadap dimensi kepercayaan akan karier (career confidence). Hal yang menjadi perbedaan dari hasil penelitian ini denganpenelitian Ataç, Dirik, \& Tetic. (2018) adalah pengaruh langsung dukungan teman terhadap adaptabilitas karier, di mana pada penelitian ini dukungan teman tidak berpengaruh langsung terhadap adaptabilitas karier, namun perlu dimediasi oleh perilaku eksplorasi karier.
Menurut Zhang \& Huang (2018) peranan dimensi dukungan teman yaitu dukungan informasi dan saran, dukungan emosional, serta dukungan role model teman terhadap perilaku eksplorasi karier adalah pemberian informasi, nasihat, semangat, dan perilaku yang baik dari teman terkait karier akan memotivasi mahasiswa untuk mencari tahu keterkaitan antara minat (internal) dan keputusan mengenai pekerjaan ataupun organisasi yang mereka cari dari lingkungan sekitar (eksternal).

Hasil penelitian menunjukkan bahwa dukungan teman berkontribusi pada perilaku eksplorasi karier, seperti halnya penelitian dari Zhang \& Huang (2018) mengenai pengaruh dukungan teman terhadap adaptabilitas karier pada mahasiswa di Tiongkok. Penelitian tersebut dilakukan pada latar budaya yang sama dengan penelitian ini, yaitu budaya timur. Hasil penelitian ini juga didukung dengan penelitian yang dilakukan oleh peneliti sebelumnya dalam konteks budaya barat, yaitu Amerika. Sebagai contoh, Kracke (2002) menjelaskan bahwa semakin sering berbicara dengan teman mengenai karier, maka hal tersebut akan semakin meningkatkan perilaku eksplorasi karier seperti mencari informasi karier, mengikuti magang, dan meninjau kembali informasi yang didapat. Demikian pula penelitian yang dilakukan oleh Khasawneh (2010) yang menemukan bahwa Semakin sering berkomunikasi dengan teman, maka individu akan semakin terbantu dalam memperoleh informasi mengenai karier dan dapat membentuk keyakinan diri dalam merencanakan karier.

Selain itu, beberapa penelitian sebelumnya juga mendukung hasil penelitian ini. Seperti pendapat yang dikemukakan oleh Kiefer, Alley, \& Ellerbrock (2015) yang menjelaskan bahwa dukungan teman membantu individu lebih merasa aman dan bahagia di lingkungan pendidikannya. Dengan kata lain, dukungan teman yang dipersepsikan oleh mahasiswa membantu mereka lebih termotivasi untuk mencari informasi terkait karier dan membantu mereka menelaah pilihanpilihan karier yang sesuai dengan minat mereka. Seperti dukungan informasi yang diperoleh dari teman, pemberian saran, dan semangat agar yakin dengan pilihan karier, serta role model yang positif, seperti role model teman yang sukses di tempat magang dapat membantu mahasiswa terpacu untuk mencari tahu berbagai informasi terkait kariernya. 
Pada penelitian ini, variabel perilaku eksplorasi karier memiliki pengaruh yang signifikan terhadap variabel adaptabilitas karier. Hal ini menandakan bahwa perilaku yang ditampilkan oleh mahasiswa bersifat positif. Seperti halnya mengumpulkan dan menganalisis informasi yang relevan terkait karier, perilaku eksplorasi karier mampu memotivasi mahasiswa untuk mempertimbangkan kemungkinan karier masa depan mereka dan mempersiapkan kemungkinan yang akan terjadi. Selain itu, penelitian ini juga sejalan dengan pendapat menurut Guan et al. (2015) yang menjelaskan bahwa kegiatan terlibat dalam eksplorasi karier mampu meningkatkan kemampuan mahasiswa untuk membuat keputusan yang disengaja dan mengambil keputusan tersebut secara lebih hati-hati. Oleh karena itu, eksplorasi karier sangat mungkin untuk memperkuat kemampuan adaptabilitas karier.

Penelitian ini juga menunjukkan bahwa perilaku eksplorasi karier menjadi mediator penuh pada pengaruh dukungan teman terhadap kemampuan adaptabilitas karier pada mahasiswa. Berdasarkan teori self-determination, ketika dukungan teman memperkuat rasa kompetensi mahasiswa dan menjadi panutan terkait karier bagi temannya, maka perilaku teman ini dapat secara langsung mempengaruhi motivasi mahasiswa untuk terlibat dalam eksplorasi karier (Deci \& Ryan, 1985; Ryan \& Deci, 2000). Perilaku eksplorasi karier akan membantu mahasiswa untuk mengeksplorasi informasi dan peluang yang berharga, serta mempersiapkan diri untuk berbagai tantangan karier. Oleh karena itu, dalam penelitian ini dijelaskan bahwa perilaku eksplorasi menjadi kunci utama yang memediasi pengaruh dukungan teman terhadap adaptabilitas karer.

Lebih spesifik lagi, perilaku eksplorasi karier memiliki pengaruh paling besar terhadap dimensi rasa ingin tahu mengenai karier. Hal ini menjelaskan bahwa eksplorasi diri (self-exploration) dan eksplorasi lingkungan (environmental exploration) memiliki peran yang sangat penting terhadap rasa ingin tahu terkait karier mahasiswa. Seperti yang dijelaskan oleh Greenhaus \& Callanan (2006) bahwa eksplorasi diri (self-exploration) merupakan aktivitas mengeksplorasi minat, nilai, pengalaman, dan tujuan karier seseorang. Dengan eksplorasi diri, mahasiswa terbantu dalam merefleksikan dan memikirkan kembali kariernya, serta membantu pemahaman mereka tentang dirinya. Dengan begitu, mahasiswa memperoleh informasi yang lebih jelas tentang keinginan dan kemampuan mereka, serta jenis lingkungan kerja yang mereka inginkan. Selain itu, eksplorasi diri juga membantu mahasiswa menyesuaikan pilihannya dengan minat mereka. Semakin sering mahasiswa melakukan eksplorasi diri yang baik, maka hal tersebut dapat berpengaruh terhadap keingintahuan mereka mengenai karier sehingga mampu mengembangkan kemampuan adaptabilitas terkait kariernya. Artinya, mahasiswa siap untuk menghadapi berbagai tantangan yang terprediksi maupun tidak terprediksi saat masa transisi sekolah ke kerja (school-to-work) (Creed \& Hughes, 2012).

Selain itu menurut Greenhaus \& Callanan (2006), eksplorasi lingkungan (environmental exploration) adalah mencari berbagai pilihan karier yang dapat dipertimbangkan seseorang untuk mengejar kariernya, di mana individu secara proaktif mengumpulkan informasi baru tentang pekerjaan, organisasi, ataupun industri yang memungkinkan untuk dipilih. Mahasiswa mengumpulkan informasi terkait pekerjaan, organisasi, ataupun perusahaan yang berguna ketika menentukan keputusan kariernya. Dengan adanya informasi tersebut, mahasiswa dapat menelaah berbagai macam pilihan yang dipertimbangkan terlebih dahulu sebelum akhirnya menentukan pilihan kariernya. Hasil ini selaras dengan penelitian yang dilakukan oleh Guan et al. (2015) yang menjelaskan bahwa pentingnya perilaku eksplorasi diri dan eksplorasi lingkungan dalam memperkuat kemampuan mahasiswa dalam mengumpulkan dan menganalisis informasi terkait karier.

Keterbatasan dalam penelitian ini adalah pengambilan data yang dilakukan hanya secara daring. Hal ini dikarenakan waktu pengambilan data bertepatan dengan keadaan pandemi Covid-19 yang mengharuskan seluruh masyarakat untuk berada di rumah. Hal ini menjadi tantangan tersendiri bagi peneliti untuk mendapatkan partisipan dari wilayah Jabodetabek. Meskipun pengambilan data dilakukan secara daring, namun semua data yang didapat dipastikan valid dan reliabel. 


\section{SIMPULAN}

Berdasarkan hasil penelitian yang telah dijelaskan sebelumnya, dapat dikatakan bahwa perilaku eksplorasi karier memediasi pengaruh antara dukungan teman terhadap adaptabilitas karier pada mahasiswa. Temuan pertama, dukungan teman terkait karier yang dipersepsikan oleh mahasiswa tidak berpengaruh langsung terhadap adaptabilitas karier. Temuan kedua, perilaku eksplorasi karier sepenuhnya memediasi pengaruh dukungan teman terhadap adaptabilitas karier pada mahasiswa. Artinya, dukungan terkait karier yang didapatkan dari teman tidak akan berpengaruh terhadap adaptabilitas karier apabila mahasiswa tidak mengeksplor informasi terkait karier mereka. Hal ini menjelaskan bahwa semakin banyak mahasiswa mendapatkan dukungan terkait karier dari temantemannya, maka semakin sering mahasiswa mencari informasi terkait karier. Perilaku eksplorasi karier yang dilakukan oleh mahasiswa ini selanjutnya akan akan membantu mereka memiliki kemampuan adaptabilitas karier. Dengan demikian, mahasiswa akan lebih mampu dalam perencanaan karier yang lebih jelas, selalu mencari informasi terkini mengenai karier yang dipilih, dan merasa yakin dengan pilihan kariernya karena mereka telah mendapatkan informasi mengenai kesesuaian minat dengan pilihan karier, memiliki keterampilan dalam mempersiapkan karier, dan telah menelaah kembali pilihan-pilihan kariernya.

Saran untuk penelitian selanjutnya yaitu dapat melihat sumber dukungan secara lengkap seperti dukungan orang tua, dosen, dan sumber dukungan lain terkait karier pada mahasiswa. Dengan melibatkan berbagai sumber dukungan, pemahaman yang diberikan dapat menjadi lebih luas dan komprehensif. Selain itu, dapat dilakukan pula analisis secara terpisah dari orang tua, dosen, dan sumber yang lainnya untuk menentukan kontribusi dukungan terhadap perilaku eksplorasi karier dan terhadap adaptabilitas karier. Tidak hanya itu, penting untuk melakukan pengambilan data tidak hanya secara daring saja, namun juga dapat dilakukan secara tatap muka untuk mengurangi bias. Perlu dingat bahwa dalam penelitian ini secara keseluruhan mahasiswa yang tersebar di Jabodetabek berbeda dengan di luar Jabodetabek dari segi keluasan fasilitas dibandingkan dengan daerah lain di Indonesia. Oleh karena itu, penelitian selanjutnya sebaiknya memperluas sampel penelitian dengan jumlah sampel yang tersebar di berbagai wilayah di Indoneisa agar hasil penelitian dapat lebih mewakilkan gambaran adaptabilitas karier mahasiswa di seluruh Indonesia.

\section{DAFTAR PUSTAKA}

Ataç, L. O., Dirik, D., \& Tetik, H. T. (2018). Predicting career adaptability through selfesteem and social support: A research on young adults. International Journal for Educational and Vocational Guidance, 18(1), 45-61.

Blustein, D. L. (1997). A context-rich perspective of career exploration across the life roles. The Career Development Quarterly, 45(3), 260 274.

Blustein, D. L., \& Flum, H. (1999). A selfdetermination perspective of interests and exploration in career development. In M. L. Savickas \& A. R. Spokane (Eds.), Vocational interests: Meaning, measurement, and counseling use (p. 345-368) Davies-Black Publishing.

Coetzee, M., \& Harry, N. (2014). Gender and hardiness as predictors of career adaptability: an exploratory study among Black call centre agents. South African Journal Of Psychology, 45(1), 81-92 https://doi.org/10.1177/0081246314546346

Creed, P. A., \& Hughes, T. (2012). Career development strategies as moderators between career compromise and career outcomes in emerging adults. Journal of Career Development, 40(2), 146-163. https://doi.org/10.1177/0894845312437207

Deci, E. L., \& Ryan, R. M. (1985). Intrinsic motivation and self determination in human behavior. New York: Plenum Press.

Ebenehi, A. S., Rashid, A. M., \& Bakar, A. R. (2016). Predictors of career adaptability skill among higher education students in Nigeria. International Journal for Research in Vocational Education and Training, 3(3), 212229.

Felsman, D. E., \& Blustein, D. L. (1999). The role of peer relatedness in late adolescent career development. Journal of Vocational Behavior, 54(2), 279-295. 
Geerlings, P., Cole, H., Batt, S., \& Martin-Lynch, P. (2016). Peer Assisted Study Sessions (PASS): Does Gender Matter?. Journal of Peer Learning, 9, 10-25.

Ginevra, M. C., Nota, L., \& Ferrari, L. (2015). Parental support in adolescents' career development: Parents' and children's perceptions. The Career Development Quarterly, 63(1), 2-15.

Greenhaus, J. H. \& Callanan, G. A. (2006). Encyclopedia of career development. SAGE Publications, Inc. https://doi.org/10.4135/9781412952675

Guan, M., Capezio, A., Restubog, S. L. D., Read, S., Lajom, J. A. L., \& Li, M. (2016). The role of traditionality in the relationships among parental support, career decision-making selfefficacy and career adaptability. Journal of Vocational Behavior, 94, 114-123.

Guan, Y., Wang, F., Liu, H., Ji, Y., Jia, X., Fang, Z., Li, Y., Hua, H., \& Li, C. (2015). Career-specific parental behaviors, career exploration and career adaptability: A three-wave investigation among Chinese undergraduates. Journal of Vocational Behavior, 86, 95-103.

Han, H., \& Rojewski, J. W. (2014). Gender-specific models of work-bound Korean adolescents' social supports and career adaptability on subsequent job satisfaction. Journal of Career Development, 42(2), 149-164.

Hayes, A. F. (2013). Introduction to mediation, moderation, and conditional process analysis. New York: The Guilford Press.

Hirschi, A. (2009). Career adaptability development in adolescence: Multiple predictors and effect on sense of power and life satisfaction. Journal of Vocational Behavior, 74(2), 145-155. https://doi.org/10.1016/j.jvb.2009.01.002

Hlad'o, P., Kvasková, L., Ježek, S., Hirschi, A., \& Macek, P. (2019). Career adaptability and social support of vocational students leaving upper secondary school. Journal of Career Assessment, 28(3), 478-495. https://doi.org/10.1177/1069072719884299

Indianti, W. (2015). Dukungan sosial dan regulasi diri dalam belajar untuk membangun adaptabilitas karier pada mahasiswa baru Universitas Indonesia. Universitas Indonesia.

karier
Jensen, A. F. (2015). Emerging adulthood (2nd ed.). New York, New York: Oxford University Press.

Ketterson, T. U., \& Blustein, D. L. (1997). Attachment relationships and the career exploration process. The Career Development Quarterly, 46(2), 167-178.

Khasawneh, S. (2010). Factors influencing the career planning and development of University Students in Jordan. Australian Journal of Career Development, 19(2), 41-48.

Kiefer, S. M., Alley, K. M., \& Ellerbrock, C. R. (2015). Teacher and peer support for young adolescents' motivation, engagement, and school belonging. RMLE Online, 38(8), 1-18. https://doi.org/10.1080/19404476.2015.11641 184

Koen, J., Klehe, U. C., \& Van Vianen, A. E. M. (2012). Training career adaptability to facilitate a successful school-to-work transition. Journal of Vocational Behavior, 81(3), 395-408.

Konstam, V., Celen-Demirtas, S., Tomek, S., \& Sweeney, K. (2015). Career adaptability and subjective well-being in unemployed emerging adults: A promising and cautionary tale. Journal of Career Development, 42(6), 463477.

Kracke, B. (2002). The role of personality, parents and peers in adolescents career exploration. Journal of Adolescence, 25(1), 19-30.

Manyijka, J., Chui, M., Bughin, J., George, K., Willmott, P., \& Dewhurst, M. (2017). A future that works: Automation, emoployement, and productivity (Issue January).

Marshall, E. A., \& Butler, K. (2015). School-to-work transitions in emerging adulthood. In The Oxford Handbook of Emerging Adulthood.

Martin, A. J., Jones, E. S., \& Callan, V. J. (2006). Status differences in employee adjustment during organizational change. Journal of Managerial Psychology, 21(2), 145-162.

Masuna, K. (2015). Hubungan antara locus of control dan adaptabilitas Karier pada lulusan sarjana Universitas Indonesia yang baru bekerja (fresh graduates). Universitas Indonesia.

Menristekdikti. (2019). Menristekdikti minta perguruan tinggi siap akan kemunculan profesi 
baru di era Revolusi Industri 4.0. Diakses dari https://lldikti1.ristekdikti.go.id/details/apps/16 14

MIKTI dan Teknopreneur Indonesia. (2018). Mapping dan database startup Indonesia 2018. Jakarta: Badan Ekonomi Kreatif RI. Diakses dari http://www.bekraf.go.id/downloadable/pdf_fil e/1812634-mapping-database-startupindonesia-2018.

Murphy, K., Blustein, D., Bohlig, A., \& Platt, M. (2010). The college-to-career transition: An exploration of emerging adulthood. Journal of Counseling and Development, 88(2), 174-181. https://doi.org/10.1002/j.15566678.2010.tb00006.x

Ryan, R. M. \& Deci, E. L. (2000). Selfdetermination theory and the facilitation of intrinsic motivation, social development, and well-being. American Psychologist, 55(1), 6878. https://doi.org/10.1037/0003-066X.55.1.68

Risdianto, E. (2019). Kepemimpinan dalam dunia pendidikan di Indonesia di Era Revolusi Industri 4.0. Didapat dari https://www.researchgate.net/publication/3324 23142_ANALISIS_PENDIDIKAN_INDONE SIA_DI_ERA_REVOLUSI_INDUSTRI_40

Salim, R. M. A., \& Preston, M. (2019). Parenting styles effect on career exploration behavior in adolescence: Considering parents and adolescent gender. Humaniora, 10(3), 249. https://doi.org/10.21512/humaniora.v10i3.580 3

Savickas, M. L. (1997). Career adaptability: An integrative construct for life-span, life-space theory. The Career Development Quarterly, 45(3), 247-259. https://doi.org/10.1002/j.21610045.1997.tb00469.x

Savickas, M. L., \& Porfeli, E. J. (2012). Career Adapt-Abilities Scale: Construction, reliability, and measurement equivalence across 13 countries. Journal of Vocational Behavior, $80(3)$, 661-673. https://doi.org/10.1016/j.jvb.2012.01.011

Steinberg, L., Dornbusch, S. M., \& Brown, B. B. (1992). Ethnic differences in adolescent achievement: An ecological perspective. American Psychologist, 47(6),
723-729. https://doi.org/10.1037/0003066X.47.6.723

Stumpf, S. A., Colarelli, S. M., \& Hartman, K. (1983). Development of the Career Exploration Survey (CES). Journal of Vocational Behavior, 22(2), 191-226. https://doi.org/10.1016/00018791(83)90028-3

Sulistiani, W., Suminar, D. R., \& Hendriani, W. (2019). The Career Adapt-Abilities ScaleIndonesian form : Psychometric properties and construct validity. Proceeding of the 4th International Conference on Education, 2, 19.

https://doi.org/10.17501/24246700.2018.4201

Super, D. E., Starishevsky, R., Matlin, N., \& Jordaan, J. P. (1963). Career development; Self-concept theory. College Entrance Examination Board. Super, D. E. (1980). A life-span, life-space approach to career development. Journal of Vocational Behavior, 16(3), 282-298. https://doi.org/10.1016/0001-8791(80)90056-1

Turkan, S., De Oliveira, L. C., Lee, O., \& Phelps G. (2014). Proposing a knowledge base for teaching academic content to English laguage learners: Diciplinary linguistic knowledge. Teachers College Record. https://www.tcrecord.org/Content.asp?Content $\mathrm{Id}=17361$

Wang, Z., \& Fu, Y. (2015). Social support, social comparison, and career adaptability: A moderated mediation model. Social Behavior and Personality: An International Journal, 43(4), 649-660. https://doi.org/10.2224/sbp.2015.43.4.649

Wentzel, K. R., Muenks, K., McNeish, D., \& Russell, S. (2017). Peer and teacher supports in relation to motivation and effort: A multi-level study. Contemporary Educational Psychology, 49, 32-45.

https://doi.org/10.1016/j.cedpsych.2016.11.00 2

Werang, B. R. (2018). Investigating students' learning motivation in Indonesian higher institution: A study from Musamus University of Merauke, Papua. International Journal of Development and Sustainability, 7(3), 10381048.

Yousefi, Z., Abedi, M., Baghban, I., Eatemadi, O., \& Abedi, A. (2011). Personal and situational 
variables, and career concerns: Predicting career adaptability in young adults. The Spanish Journal Of Psychology, 14(1), 263-271. https://doi.org/10.5209/rev_sjop.2011.v14.n1. 23

Zacher, H. (2015). The importance of a precise definition, comprehensive model, and critical discussion of successful aging at work. Work, Aging and Retirement, 1(4), 320-333. https://doi.org/10.1093/workar/wav020

Zhang, H., \& Huang, H. (2018). Decision-making self-efficacy mediates the peer support-career exploration relationship. Social Behavior and Personality: An International Journal, 46(3), 485-498. https://doi.org/10.2224/sbp.6410 